Published on Reviews in History (https://reviews.history.ac.uk)

\title{
Quakers and Puritans review article
}

Review Number: 1881

Publish date: Thursday, 21 January, 2016

Author: Abram Van Engen

ISBN: 9780199379637

Date of Publication: 2015

Price: $£ 43.19$

Pages: 328pp.

Publisher: Oxford University Press USA

Publisher url: https://global.oup.com/academic/product/sympathetic-puritans-9780199379637?cc=gb\&lang=en\&

Place of Publication: Cary, NC

Author: Jordan Landes

ISBN: 9781137366689

Date of Publication: 2015

Price: $£ 60.00$

Pages: 264pp.

Publisher: Palgrave Macmillan

Publisher url: http://www.palgrave.com/page/detail/london-quakers-in-the-transatlantic-world-jordanlandes/?isb=9781137366672

Place of Publication: Basingstoke

Reviewer: Thomas D. Hamm

We are now a generation into an 'Atlantic turn' in writing early American history. Jordan Landes and Abram C. Van Engen make welcome, but different, contributions through their arguments about emotions in Puritan New England and networking by London Quakers.

Van Engen's book, based on his dissertation at Northwestern University, will be an important work for students of colonial New England, Puritanism, and the history of the emotions. His focus is on the concept and practice of sympathy among Puritans in 17th-century New England. He thus undermines yet another popular stereotype of Puritans, that they were uniformly grim, cold, steely, flint-hearted stoics whose only display of feeling was wrath directed at the ungodly. Continuing a tradition that goes back to Perry Miller and Edmund S. Morgan, he finds that Puritans were intensely emotional, and that the particular emotion of sympathy was central to Puritan theology and life. 
Van Engen opens with a genealogy of the concept of sympathy in American intellectual life, and particularly of the conviction that Puritans were utterly lacking in it. He ascribes this partly to the influence of Nathaniel Hawthorne, whose novels and short stories probably fixed the image of the unfeeling Puritan more strongly in the American mind than any historian, but also to the 'scribbling women' novelists like Harriet Beecher Stowe and Catherine Maria Sedgwick. Proceeding from the conviction that progress depended on repudiating the grim, unfeeling Calvinism of earlier generations, their case against Puritanism was based in large part on its lack of feeling for fellow human beings. The most influential scholarly case for this point of view came in 1977, with Ann Douglas's The Feminization of American Culture.

Van Engen argues that such a view is ill founded. Puritans attached great significance to sympathy, in two modes. One was fellow-feeling. Quoting John Winthrop's well-known 1630 address, 'A Model of Christian Charity', Van Engen notes Winthrop's conviction that New England would become 'a city upon a hill' only if there was 'a sensiblesness and sympathy of each other's conditions [that] will necessarily infuse into each parte a native desire and endeavor, to strengthen, defend, preserve, and comfort the other ' (p. 26). Indeed, Van Engen concludes, 'a hope of sympathy forms the heart of Winthrop's Model of Christian Charity - a vision for society in which reciprocal affections become fundamental in community well-being ... Winthrop preached mutual affections as vital for the common good. To survive and flourish in the wilds of this new world, Winthrop declared, the community would need not just right doctrine, right worship, and right laws, but also-and especially_right hearts' (pp. 25-6).

Sympathy was also a critical element in the search for assurance of election. Puritans in the era of the Great Migration to New England admitted to church membership only those who could demonstrate to the satisfaction of their pastors and congregations that they were 'visible saints,' among the elect whom God had predestined to salvation by being justified and sanctified. This was a tricky business. All Puritans believed that one found the necessary evidence through 'the testimony of the Holy Spirit' (p. 63). But, citing Joel Beeke, Van Engen notes that three different understandings had emerged by the 1630s. One saw the testimony of the Spirit in a godly life. Another 'held that the Holy Spirit witnesses not only with, but also to, a believer: it was "something in addition", opening the door to some form of direct testimony or religious experience, but still tying it closely to fruits and evidence of a godly life' (p. 63). A final group verged on mysticism, 'describing full assurance as an "immediate light, joy unspeakable, transcendent, glorious, and intuitive"” (p. 63).

Sympathy here enters the picture. Van Engen argues that Puritans saw it as one of the marks of sanctification; 'love of the brethren' was not a duty of charity toward fellow believers, but 'a feeling, an experience, not a deed ... not a duty performed' (p. 70). It was strong evidence of assurance of election. As Van Engen sums up the case of one Puritan memoirist, Roger Clap: 'This sensation of love, this inner experience, provided comfort in times of trial; he must love God and God must love him because, quite simply, he loved God's people. His inner response toward the community marked him as a fellow member' (p. 71).

Van Engen uses this insight to venture a new understanding of the central conflict of New England Puritanism in the 1630s, the Antinomian controversy. He argues that the controversy was primarily theological, noting that 'when letters first passed between Thomas Shepard and John Cotton (the leading ministers on either side), the primary issue was pastoral, not political: they debated assurance and salvation, not authority and stability' (p. 59). Van Engen acknowledges that as the debates progressed, they did come to involve questions of authority and leadership. But these grew out of different understandings of theology that both sides saw as vital, differences that largely involved questions of sympathy. When Anne Hutchinson, in open court, avowed that she was sure of her salvation because of immediate personal revelation, she was embracing a particular understanding of assurance. Her opponents, in contrast, looked on immediate revelation as an invitation to anarchy. But when they pointed to 'love of the brethren' (p. 77) as evidence of election, Hutchinson and her spiritual mentor, John Cotton, dismissed this as cheap grace; they demanded the sort of ecstatic experience that few Puritans could claim as assurance. As Van Engen aptly 
concludes, modern readers usually sympathize with Hutchinson, a gifted woman battling persecuting male magistrates. But, 'it was the antinomians who lessened the value of sympathy (and all other relatively ordinary experiences), while the elders attempted throughout the controversy to maintain the salvific importance of fellow feeling. Precisely because it was so important to them, they could not tolerate a group of people who rejected sympathy as a sign of grace' (p. 89).

In an especially interesting chapter, Van Engen then explains how New England, supposedly united by mutual love, could fall victim to the divisions that the Antinomian controversy manifested. The Antinomians had a ready explanation. True Christians were always a beleaguered minority, persecuted by the ungodly. The Antinomians' chief clerical advocate, John Wheelwright, in an incendiary comparison exalting the love of Christians for ach (and clearly implying that those who opposed/did not love him were false Christians), made a comparison to the persecuted Christ. As Van Engen summarizes, 'Wheelwright cast himself and his fellow saints as a persecuted minority. Christ is always opposed, he declared. When Christ was born, Herod tried to kill him; when he began his ministry, legions turned against him; in his death and burial, Christ showed that the world will always hate him' (p. 97). Thus Wheelwright characterized the motives of his opponents, which in turn explains why the elders of the colony, led by John Winthrop, saw theological difference as verging on sedition. They also had an explanation, seduction, a corruption of love, with Anne Hutchinson as the seductress. So when Hutchinson was excommunicated, she was exhorted to 'learne no more to blaspheme[,] to seduce and to lye' (p. 109). Because they had loved Hutchinson as a sister in Christ, her followers were led into error through their sympathy with her.

The transatlantic element of Van Engen's book emerges in chapter four, 'Transatlantic relations and the rhetoric of sympathy'. Sympathy emerges as a new justification of the anti-separatist stance of orthodox Puritans: 'Separation would take them out of brotherly love, out of the possibility of debate and persuasion. Without a continued union, the godly of New England could be quietly ignored' (p. 119). In this and the following chapter, Van Engen focuses on three well-known Puritan writers - Anne Bradstreet, John Eliot, and Edward Johnson - and the otherwise obscure minister of the church in Taunton, Massachusetts, William Hooke - to show how displays of sympathy first bound together and then distinguished Puritans in Old and New England in the 1640s and 1650s. Thus in the 1630s the godly folk of New England suffered with Puritans facing persecution by king and prelates and in the 1640s they rejoiced at the victory of the righteous over the ungodly. But, in the 1650s, when Cromwell and the Independents did not emulate the New England Way, they suffered with the righteous remnant back in England.

Van Engen's last two chapters take up Puritan relations with the native Algonquian peoples of New England, especially the converts, or 'Praying Indians'. Van Engen focuses on the written works of John Eliot, the best known of Puritan missionaries. Once again sympathy is central. The seal of the Massachusetts Bay Company, after all, bore the image of an Indian pleading: 'Come over and help us' (p. 146). Sympathy was also central to judging the validity of Indian conversions. Puritans looked for tears - tears that signaled sorrow for one's previously sinful life and unworthiness, tears that would stir the sympathies of other believers.

Sympathy had its limits, however, as Van Engen's analysis of one of the best-known Puritan captivity narratives, Mary Rowlandson's The Sovereignty and Goodness of God shows. Captured with several family members by an Indian war party in 1676 after an attack on Lancaster, Massachusetts, Rowlandson saw a daughter die in captivity before she was released. Rowlandson's account had two purposes. One was to gain the sympathy of Puritan readers with accounts of suffering at the hands of savages and separation from family and fellow Christians. Rowlandson, to be sure, sometimes encountered kindness at the hands of her captors. But Van Engen argues that Rowlandson was always quick to counter these feelings of sympathy with denunciation, concluding: 'fellow-feeling with the wrong people could threaten one's identity' (p. 198).

Van Engen concludes with a consideration of the state of Puritan sympathy at the end of the 17th century. 
He creatively employs accounts of the Salem witch trials, where one of the strongest signs of evidence against the accused was lack of sympathy for sufferers. But he also sees change, as the Latitudinarians reinterpreted sympathy. For them, it was inherent in all humans. No longer was it evidence of grace or redemption.

Jordan Landes's book is more tightly focused and less sweeping, a study of the structures, based in London, that English Quakers created between 1660 and 1700 to coordinate communication and trade with Friends 'beyond the seas', first in the West Indies, and increasingly in North America. Friends had first ventured across the Atlantic in 1655, and regularly sent letters home reporting on 'how Truth prospered' in their parts. In the 1660s, responding both to persecution and a perceived need to enforce group discipline, Friends, led by founder George Fox, had established two institutions in London, the Second Day (Monday) or Morning Meeting, and the Meeting for Sufferings. Made up of 'weighty' (spiritually gifted) Friends, the former had jurisdiction over 'Public Friends' who were recognized as ministers, as well as giving an imprimatur to Quaker books, while the latter (all male) engaged in political lobbying and tried to help relieve Friends who were suffering for their beliefs. The membership of the two groups overlapped, as Public Friends were often perceived as possessing gifts appropriate for the work of the Meeting for Sufferings.

Landes confirms the findings of previous historians that after 1670 'weighty' Friends in London attempted to keep a close watch, not only on Friends in the British Isles, but those in the colonies. They did so in three ways. The first was by dispatching approved Quaker books, often multiple copies, to Quaker congregations and individuals. The second was by accrediting the visits of ministers who felt led to visit colonial Quakers. When a Public Friend felt led to travel abroad, it became an expectation that he or she should acquire a minute of unity from the Morning Meeting, both certifying the good standing of the Friend and the blessing of the Morning Meeting on the particular visit contemplated. Friends abroad would look with skepticism and refuse hospitality to ministers traveling without proper minutes. Finally, following the practice of the first generation of Friends, both the Morning Meeting and the Meeting for Sufferings issued epistles, letters of advice and exhortation that were generally received deferentially by colonial Friends. Colonial Friends were slow to set up their own printing businesses, which left them dependent on London for their books.

Quaker involvement in the Atlantic world was not limited to communications and travel on matters of church polity. By 1700, some of the largest and wealthiest merchants in London were Friends. In a world where reputation was critical to forming credit ties and networks, the aura of honesty and dependability that had come to be associated with Friends was a distinct asset. Landes notes that official Quaker exhortations to thrift, honesty, and avoidance of speculation and debt were not unique to Friends, but Friends were probably more vigorous in enforcing them. Landes concludes that 'in many respects, the activities of Quaker merchants in London did not vary greatly from those of non-Quakers, nor were they held back by their religion' (p. 101). Before 1725, at least, London Quaker merchants showed little reluctance to trade in slaves, nor were their investments markedly different from those of other merchants. But, Landes argues, Friends probably had an advantage from the formal and informal channels of Quaker communication. Not only goods, but also people, regularly crossed the Atlantic, and Landes devotes one chapter to Quaker emigration. Here her conclusions are based largely on the work of other historians, not so much presenting original findings as placing Quaker emigration, especially to the Delaware Valley, in the larger context of Quaker Trans-Atlantic ties.

Landes concludes with an overview of Quaker perceptions from both sides of the Atlantic. Quaker farmers in the new world did not differ from their non-Quaker neighbors in agricultural practices. London Friends saw colonial Friends in need of continuing oversight and exhortation, attention that Friends in the colonies did not always receive graciously. By the mid-18th century, Landes concludes, London had been transformed from the center of the Quaker world into the hub of a web of inter-related Quaker communities in the North American colonies, and the British Isles.

Van Engen's is the more original work, and probably will be of interest to a wider range of scholars. It proves that there is still something original to be said about Puritanism. Landes's work is capably presented, 
and her conclusions are always measured and grounded in appropriate evidence. But its appeal is likely to be limited to specialists in Quaker history because her contribution is not so much new insight into the existence of an Atlantic network of Quakers - we knew that existed - but careful reconstruction of how it worked.

Jordan Landes is happy to accept this piece and would like to thank the reviewer.

Abram van Engen is happy to accept this review and does not wish to comment further.

Source URL:https://reviews.history.ac.uk/review/1881

\section{Links}

[1] https://reviews.history.ac.uk/item/145475 [2] https://reviews.history.ac.uk/item/145476 